\title{
Innovation based learning contextual for thermochemistry topic in senior high school
}

\author{
Nurhayani ${ }^{1,2^{*}}$, Marini Damanik ${ }^{2}$, Marudut Sinaga ${ }^{2}$ \\ 'Sekolah Menengah Kejuruan Farmasi APIPSU, Medan, Indonesia \\ ${ }^{2}$ Department of Chemistry, Universitas Negeri Medan, Medan 20221, Indonesia
}

\begin{abstract}
:
The implementation and development of teaching materials purposed to find the topic based on the criteria of National Education Standard Agency (BSNP). The student learning outcomes increase in thermochemistry topic based on the modules contextual. The population in this study were all students of class XI MIA SMAN 2 Percut Sei Tuan consists of 4 classes, while the students of each class were \pm 35 people. The sample used in this study consists of two classes randomly selected. The first class as the experimental which given learning module as a contextual-based teaching materials, however the control class was given without it. The instrument used assessment BSNP that shared to 1 teacher and 2 lecturers. The test used multiple-choice with 20 questions that were valid and reliable. As a prerequisite for testing, the hypothesis of learning outcomes both groups of samples were tested for homogeneity using programs Microsoft Excel. The results of the study showed that teaching materials met BSNP criteria that content $=4.16$; language $=4.14$; presentation $=4.04$; Integrity $=4.18$ by lecturer. Furthermore, the data achieved of content $=4.32$; language $=4.21$; presentation $=4.20$; integrat $y=4.13$ by teacher. There are valid criteria and no need revision. The tests performed two sample groups were homogeneous. Hypothesis testing is done by using Paired Sample T-Test with SPSS 21. The hypothesis test concludes that the chemical learning outcomes of students uses teaching materials contextual-based module is higher than the student learning outcome without it in the thermochemistry module.
\end{abstract}

Keywords:

contextual; module teaching materials; outcomes learning

\section{Introduction}

In chemistry learning students 'interest is very small, this is because students have different learning speeds, the contents of the book are less motivating, students have their own learning styles, and the material delivered is less associated with everyday life so students' learning experiences are small (Dartin, 2011; Tarigan, 2015). Therefore, efforts to improve the quality of chemical learning are currently being carried out, included the improving the quality of teaching materials.

Modules are learning materials that can encourage and give students the opportunity to learn independently and to study appropriately in accordance with students' abilities. Modules are chosen to help contextual based learning because students can build their own knowledge according to their abilities. The advantages of using modules

\footnotetext{
* Corresponding author.

nurhayani_eks@yahoo.com

doi: https://doi.org/10.2 4114/jpkim.v10i3.12718
}

in learning are that student motivation can be improved, student assignments can be identified quickly, student learning outcomes can be adjusted to students' abilities, and it is more effective and efficient in learning (Novilia et al. 2017).

In addition to teaching materials, models and learning methods also play a role in achieving learning goals. The right learning model and method to make students actively involved in learning, namely with a contextual approach (Contextual Teaching Learning) which in essence wants more meaningful learning activities by connecting chemical learning with students' daily lives (Silaban \& Simangunsong, 2015; Manalu et al. 2016; Silaban, 2017). Learning using a contextual approach in it contains seven components which consist of constructivism, modeling, finding, asking questions, learning society, real assessment, and reflection. The contextual approach can give students the opportunity to construct new knowledge with the experiences they have. With a contextual approach students are also invited to 
discover their own chemical concepts, so they are able to understand more deeply what they have found (Retnasari et al. 2016).

In some previous studies conducted by Ulfa (2016), states that the use of learning modules can improve learning outcomes or increase students' interest in learning material. Vaino's et al. (2012) reported that the student motivation $(\mathrm{N}=416)$ was significantly higher related to modules contextually specifically designed compared to previous chemistry lessons. According to Matondang (2016) on the development of contextual-based teaching materials on thermochemical subjects in high school showed that student learning outcomes using innovative modules are higher than using the original textbook.

Based on previous research described above, it can be seen that learning using modules can improve student learning outcomes. In this study, the authors developed a contextually based module on the topic of thermochemistry. The development of the Thermochemical Module is based on the BSNP 2006. The module development procedure consists of needs analysis, design, validation, trial and revision. The purpose of enrichment of the thermochemical module is to find the feasibility and effectiveness of Thermochemical Modules to improve yield based on the percentage of feasibility accesed.

\section{Materials and Methods}

This research was conducted at school SMA Negeri 2 Percut Sei Tuan in 2017/2018 academic year. The sample of this research consisted of 30 students of $\mathrm{XI}-\mathrm{MIA} 1$ as the class experimental which given learning module as a contextual-based teaching materials, and 30 students of XI-MIA 2 as the control class was given without it. The experimental design of this research was Pre-test Post-test Control Group Design which is showed on Table 1.

Table 1

Research design

\begin{tabular}{cccc}
\hline Group & $\begin{array}{c}\text { Pre- } \\
\text { test }\end{array}$ & Treatment & Post-test \\
\hline Experimental & $\mathrm{T}_{1}$ & $\mathrm{X}$ & $\mathrm{T}_{2}$ \\
Control & $\mathrm{T}_{1}$ & $\mathrm{Y}$ & $\mathrm{T}_{2}$ \\
\hline
\end{tabular}

$X$ represents learning using the Thermochemistry Module based on contextual learning, and $\mathrm{Y}$ represents learning without using the Thermochemistry Module based on contextual learning. $\mathrm{Tl}$ is pre-test before using Thermochemistry Module, and T2 is post-test after using Thermochemistry Module.

The instrument used the assessment Thermochemistry Module is BSNP questionnaire that shared to 1 teacher and 2 lecturers. The cognitive test was collected. The test instrument was trialed to 28 SMA Negeri I Percut Sei Tuan students. Based on the trial, 24 questions were found to be valid and the Kuder \& Richardson (KR-20) reliability coefficient score for the instrument was 0.87 . The data were analyzed with descriptive quantitative analysis technique. Data of paired sample t-test and gain score from students' pre-test and post-test results were used for analysis. The Thermochemistry Module is effective when there is a difference between pre-test and post-test scores based on paired sample t-test and gain score result. The gain score can be measured with this formula:

$\% \mathrm{~g}=\frac{\text { posttest score }- \text { pretest score }}{\text { maximum score }- \text { pretest score }} \times 100$

Meltzer (2002) said that gain score has three criteria, which are explained in Table 2.

Table 2

Gain score criteria

\begin{tabular}{ll}
\hline $\mathrm{g} \leq 0,3$ & Low \\
\hline $0,3<\mathrm{g} \leq 0,7$ & Medium \\
\hline $\mathrm{g}>0,7$ & High \\
\hline
\end{tabular}

The research procedure to find the influence of the Thermochemistry Module to increase students' cognitive learning outcomes is explained below:

1. The development of the Thermochemistry Module and research instrument;

2. Validity test of the thermochemistry module and research instrument to know their feasibility;

3. Trial of test instruments;

4. Trial of the thermochemistry module in experimental class (XI-MIA I SMA Negeri 2 Percut Sei Tuan); and

5. Test of students' cognitive learning outcomes to find the influence of the the thermochemistry module to increase students' cognitive learning outcomes.

The hypotheses are $\mathrm{HI}$ : The increase student learning outcomes using the Thermochemistry Module based on contextual learning is higher than student learning outcomes without using the Thermochemistry Module based on contextual learning. Ho: The increase student learning 
outcomes using the Thermochemistry Module based on contextual learning is lower than student learning outcomes without using the Thermochemistry Module based on contextual learning. Hypothesis test was used to find the influence of the Thermochemistry Module to increase students' cognitive learning outcomes. The hypothesis will be accepted if sig. (2-tailed) < $\alpha=0.05$.

\section{Results}

\section{Standardization of thermochemistry module}

The results of the analysis, the assessment carried out by three expert validators consisting of two lecturers from UNIMED FMIPA Department of Chemistry and one chemistry teacher at SMA Negeri 2 Percut Sei Tuan. Thermochemistry Module for high school/ MA class $\mathrm{XI}$ get the average shown in Table 3 and Table 4. Based on Tables 3 and 4 , it can be seen that the respondents gave positive opinions of the development results the Thermochemistry Module and valid did not need revisions.

Table 3

Results of standardization by lecturers

\begin{tabular}{lll}
\hline \multicolumn{1}{c}{ Criteria } & Mean & Validation Criteria \\
\hline Content & 4,16 & valid and no need revision \\
Language & 4,14 & valid and no need revision \\
Presentation & 4,04 & valid and no need revision \\
lntegrity & 4,18 & valid and no need revision \\
\hline
\end{tabular}

Table 4

Results of standardization by teacher

\begin{tabular}{lll}
\hline \multicolumn{1}{c}{ Criteria } & Mean & Validation Criteria \\
\hline Content & 4,32 & valid and no need revision \\
Language & 4,21 & valid and no need revision \\
Presentation & 4,20 & valid and no need revision \\
Integrity & 4,13 & valid and no need revision \\
\hline
\end{tabular}

The increase in students' cognitive pre-test and post-test scores

The aim of this research is to find the influence of the Thermochemistry Module which has been previously developed. The influence of the Thermochemistry Module is showed by an increase in the pretest to post-test scores. The paired sample t-test analysis result and the gain score analysis of students' cognitive test (pre-test and post-test). The students' cognitive pre-test and post-test scores shown in Fig 1. Based on Fig I, it can be seen that there is an increase in student learning outcomes both in the experimental class and in the control class. The post-test value can increase due to given of teaching on thermochemical subject material in the experimental class and the control class.

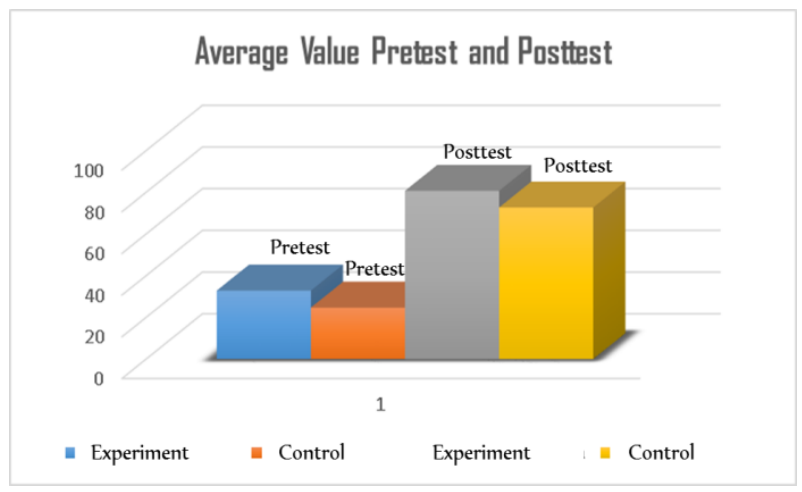

Fig 1. Average value pretest and posttest

\section{The paired sample t-test result}

The influence of the Thermochemistry Module to increase cognitive learning outcomes was also determined by paired sample t-test. The aim of paired sample t-test is to find the difference of students' learning outcomes. Paired sample t-test analysis result calculated using SPSS 21 for Windows program based on students' cognitive pre-test and post-test scores shown in Table 5.

Tabel 5.

Paired sample t-test results

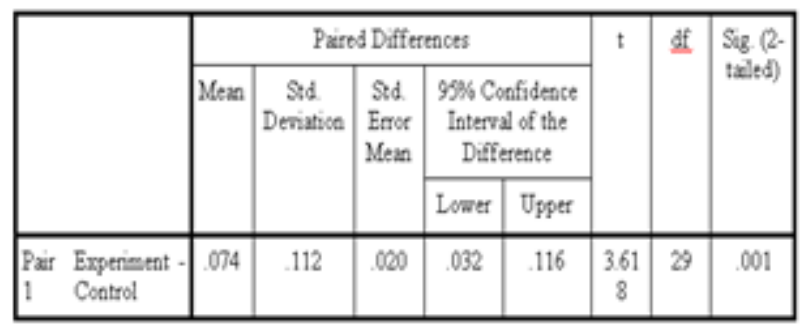

Based on Table 5, it is known that Sig.(2-tailed) $<\alpha$ is $0,001<0,05$ so $\mathrm{Hl}$ was accepted. It can be concluded that there was the increase student learning outcomes using the Thermochemistry Module based on contextual learning is higher than student learning outcomes without using the Thermochemistry Module based on contextual learning.

\section{The students' cognitive gain score results}

The influence of the Thermochemistry Module was not only determined by paired sample t-test analysis result, but also gain score analysis result. The gain scores for students' cognitive pre-test and post-test scores are displayed in Table 6 . Based on Table 6 , the percentage of increase in chemistry learning outcomes of students in the 
experimental class of $71.16 \%$, while in the control class an increase of $63.74 \%$. The increase chemistry learning outcomes of students in the experimental class with a high category while in the control class with a medium category.

Table 6

Gain score results

\begin{tabular}{lllll}
\hline \multicolumn{1}{c}{ Class } & Criteria & Mean & \% Gain & Category \\
\hline Experime & \%g< $30=$ & 0,7116 & $71,16 \%$ & High \\
nt & Low; & & & \\
Control & $30<\% g>70=$ & 0,6374 & 63,74 & Medium \\
& Medium; & & $\%$ & \\
& $\% g>70=$ & & & \\
& High & & & \\
\hline
\end{tabular}

\section{Discussion}

The discussion of the study showed that teaching materials met BSNP criteria that Content $=4.16 ;$ Language $=4.14 ;$ Presentation $=$ 4.04; Integrity $=4.18$ by lecturer. Furthermore, the data achieved of Content $=4.32$; Language $=$ 4.21; Presentation $=4.20$; integrat $y=4.13$ by teacher. There are valid criteria and no need revision. The tests performed two sample groups were homogeneous. Hypothesis testing is done by using Paired Sample T-Test with SPSS 21. The hypothesis test concludes that the chemical learning outcomes of students uses teaching materials contextual-based module is higher than the student learning outcome without it in the thermochemistry module.

This is in accordance with previous studies states that the use of learning modules can improve learning outcomes or increase students' interest in learning material and was significantly higher related to modules contextually specifically designed compared to previous chemistry lessons (Situmorang, 2014). Meanwhile, the authors found some difficulties while doing this research. The first difficulty was time management when implementing the Thermochemistry Module to the trial subjects (Febliza \& Yulis, 2018). The second difficulty that the students were not familiar with chemistry learning contextual (Manalu et al. 2016). Based on the authors' observations in SMA Negeri 2 Percut Sei Tuan, Thermochemistry topic was taught using the exercises item model; in addition the students only used book from school as required by the Curriculum 2013.

\section{Conclusion}

Based on the research results and discussion, it can be concluded that the research showed that teaching materials thermochemistry module met
BSNP criteria that content $=4.16$; language $=4.14$; presentation $=4.04$; Integrity $=4.18$ by lecturer . Furthermore, the data achieved of content $=4.32$; language $=4.21$; presentation $=4.20$; integrat $y=$ 4.13 by teacher. There are valid criteria and no need revision. Based on the processing of existing data, the student learning outcomes obtained using the teaching materials contextual-based thermochemistry module is higher than the student learning outcome without thermochemistry module.

\section{References}

Dartin. (2011). Analysis and standardization of class $x$ semester ii chemistry books based on content standards of ktsp. Thesis. Postgraduate Program. Medan State University, Medan.

Febliza, A., \& Yulis, P.A.R. (2018). Mapping learning difficulties in general chemistry course. Jurnal Pendidikan Kimia, 10(2), 372376.

Manalu, E., Silaban, S., Silaban, R., \& Hutabarat, W. (2016). The development of chemical practice guidebook colloid system-based integrated contextual character values. Jurnal Pendidikan Kimia, 8(2), 8-13.

Matondang, N.l. (2016). Development of contextual based learning materials in thermochemistry subjects in high school. Thesis. FMIPA. Medan State University, Medan.

Meltzer, D.E. (2002). The relationship between mathematics preparation and conceptual learning gains: A possible "hidden variable" in diagnostic pretest scores. American journal of physics, 70(12), 1259-1268.

Novilia, L., Iskandar, S.M., \& Fajaroh, F. (2017). The effectiveness of colloid module based on guided inquiry approach to increase students' cognitive learning outcomes. International Journal of Education, 9(1), 17-23.

Retnasari, R., Maulana, M., \& Julia, J. (2016). Pengaruh pendekatan kontekstual terhadap kemampuan koneksi matematis dan motivasi belajar siswa sekolah dasar kelas iv pada materi bilangan bulat. Jurnal Pena Ilmiah, 1(1), 391-400.

Silaban, S., \& Simangunsong, N.S.D. (2015). Pengaruh model pembelajaran contextual teaching and learning (ctl) terhadap hasil belajar siswa pada pokok bahasan sistem koloid. Jurnal Pendidikan Kimia, 7(01), 95-101.

Silaban, S. (2017). Dasar-dasar pedidikan matematika dan ilmu pengetahuan alam. Medan: Harapan Cerdas Publisher.

Situmorang, M. (2014). Effectiveness of innovative learning modules to improve learning 
outcomes in teaching the reaction rate. Research Journal for Education, 20 (2), 139-147.

Tarigan, D. A. B. (2015). The development and standardization of senior high school chemistry textbook for year $x i$ at semester $i$ rsbi class based on contents standard of ktsp. Jurnal Pendidikan Kimia, 7(3), 41-52.

Ulfa, F. (2016). Development of project-based module teaching materials on learning alkenes and alchae in high school. Thesis. FMIPA. Medan State University, Medan.

Vaino, K., Holbrook, J., \& Rannikmäe, M. (2012). Stimulating students' intrinsic motivation for learning chemistry through the use of contextbased learning modules. Chemistry Education Research and Practice, 13(4), 410-419. 